\title{
The Application Of Historical And Modern Management Theories In The Financial Industry: An Analysis Of How Management Practices Affect Employee Turnover!
}

Rolando M. Ochoa, Nova Southeastern University, USA Bahaudin G. Mujtaba, Nova Southeastern University, USA

\begin{abstract}
Employee turnover has always been and continues to be a challenge for managers and entrepreneurs. As managers in the banking industry continue to experience the negative effects of voluntary turnover of tellers and other critical positions, they persist to look for ways to do their jobs better and provide more competitive services to their customers. Some of the literature indicates that a number of the current management practices, fueled by questionable management theories, could be contributing to the increase voluntary turnover ratios. This paper is a literature review as well as application of general management theories and their effect on voluntary turnover in the service industry. It further offers analysis and suggestions for managers, especially for those who are in the service and banking industries. The authors' observations, suggestions, and recommendations are based on research and nearly fifty years of combined experience as managers and leaders in the banking and service industries.
\end{abstract}

Keywords: Voluntary Turnover, Management Theories, Financial Industry, Job Satisfaction, Organizational Commitment

\section{INTRODUCTION TO THE EVOLUTION OF MANAGEMENT}

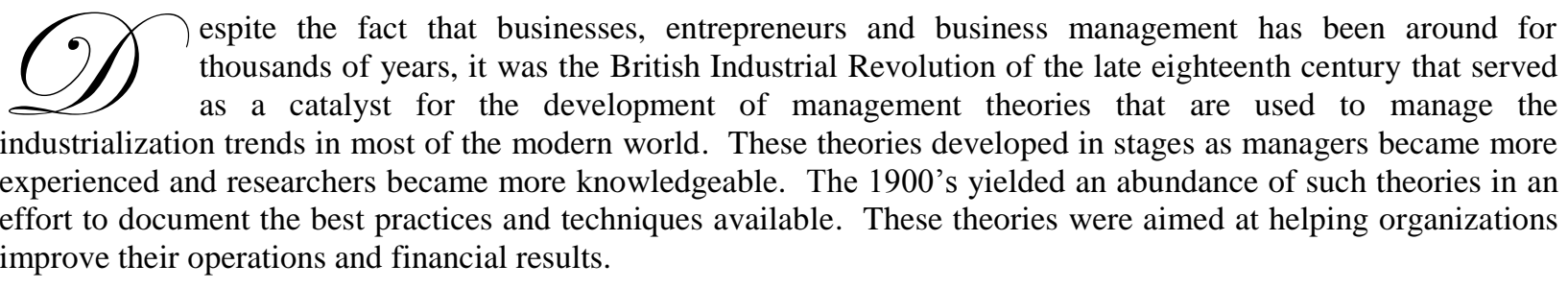

Some of the theorized vital areas were organizational structure, strategy, leadership, and motivation. The management of employees became a crucial part of the industrialization process as retention of the labor force became more important. New ways of organizing and reacting to change were derived from the improvements in production and staffing structures.

Several individuals were recognized as key to the development of these early management theories. Frederick W. Taylor (1856-1915) is considered the father of scientific management, and Henri Fayol (1841-1925) is known as the father of administrative management. Both of these men contributed to the development of the management field as we know it today. Managers have evolved from using a paternalistic approach in the early 
days, to the practice of maximizing stockholder value which is prevalent today. These changes in leadership and management style affect the loyalty and motivation of employees because they feel that achieving organizational goals is all that counts. There is ample literature linking voluntary turnover to the lack of satisfaction and motivation among employees.

In the Job Enrichment Theory or Two-Factor Theory, Herzberg (1959) stipulates that there is a difference between a hygiene factor, such as salary level, and a motivation factor, such as organizational commitment. When salary reaches an acceptable level, it decreases dissatisfaction, and when organizational commitment reaches an acceptable level, it increases satisfaction. Herzberg reasoned that because the factors causing satisfaction are different from those causing dissatisfaction, the two feelings cannot be treated as opposites of one another. The opposite of satisfaction is not dissatisfaction, but rather, no satisfaction. Similarly, the opposite of dissatisfaction is not satisfaction, but rather no dissatisfaction.

Herzberg proposes that the employee operates from what he calls a "neutral point," with neither positive nor negative attitudes towards his/her job (1959, p. 111). The factors influence employees' job attitudes by affecting dissatisfaction or satisfaction. Employees will exhibit low organizational commitment and satisfaction if the organization utilizes management theories that do not recognize the importance and contributions of the workers. The authors of this study propose that the creation and ineffective or ill-timed application or implementation of certain management theories can and have contributed to voluntary employee turnover.

\section{Job Satisfaction and Organizational Commitment}

Job satisfaction and its relationship to voluntary turnover has been extensively studied since the mid1950 's, and continues to be an important topic due to the implicit and explicit costs of voluntary turnover to organizations. From the theoretical assumptions of March and Simon (1958) linking job satisfaction and turnover, many researchers have presented and supported hypotheses reporting consistent correlations between job satisfaction and employee withdrawal (Locke 1968, 1976). Others have presented findings supporting that significant job dissatisfaction stimulates thoughts of quitting (Mobley, 1977). Mobley (1978) also concluded that there is a significant correlation between job satisfaction, intention to quit, and searching for another job. Others (Fishbein, 1967; Locke, 1968; Locke, Cartedge, \& Knett, 1970; and Kraut, 1975) have also presented evidence to support that intention to quit is the immediate precursor to actually quitting.

Four distinguished researchers (Porter, Steers, Mowday, \& Boulian, 1974) took a different approach by studying the changes that occur across time when they measured organizational commitment and job satisfaction as each relates to turnover. They felt it was more logical to measure patterns of change in attitude over time, and how these changes were related to the propensity to leave or stay. Their study focused on the attitude constructs of organizational commitment and job satisfaction, and compared their predictive powers in defining the differences between those who stay and those who leave. They used actual turnover data from a sample population that was categorized into those who stay and those who leave. For each group, the mean scores were calculated for both organizational commitment and job satisfaction.

When these results were analyzed longitudinally, they found that the relationship between attitudes and turnover grew stronger over time. They also found that the relationships between turnover and the two attitude constructs (organizational commitment and job satisfaction) were related yet distinguishable. The relationship between organizational commitment and satisfaction with the work itself had the highest correlation coefficient. Their overall findings suggest that general attitudes toward the organization have more impact on the decision to stay than the attitude toward the job.

Another study, that used Mobley et al. (1979) as its basis was, conducted by Youngblood, Mobley and Meglino (1983) with a group of Marine Corps recruits. This research concentrated on four major integrative components: intention to quit, job satisfaction, expected utility of the present role, and expected utility of the alternative roles outside the present organization. The results for those who quit and those who stayed showed a marked difference. The results also supported the concept that behavioral intention to quit serves as a diagnostic precursor of turnover. In addition, this research reaffirmed that changes in satisfaction over time affect turnover. 
Some of the previous research overlooked the causal relationship between job satisfaction and organizational commitment. Williams and Hazer (1986) wrote an article reviewing this relationship, and developed the hypothesis that job satisfaction is a causal antecedent. They also concluded that organizational commitment distinguishes itself from job satisfaction in that the former is an effective response to the whole organization, while the latter represents an effective response to specific aspects of the job. Their study also attempted to support that personal and work characteristics have no direct effect on turnover intentions. They proposed that personal and work characteristics had an indirect effect on satisfaction and commitment.

The additional research of Steers and Porter (1983) defines organizational commitment in two different ways: as a behavior or an attitude. The behavior is when the employee is committed because it is too costly to leave due to pay, tenure, and benefits. The attitudinal approach is considered more positive because the employee identifies with the organization and its goals.

A path analysis based on previous findings was conducted by Tett and Meyer (1994), where they supported the model claiming that organizational commitment takes longer to develop, but is more stable than job satisfaction. This model suggests that job satisfaction acts only as an indirect influence on the intention and/or the decision to quit. It also suggests that organizations develop mechanisms to increase employee satisfaction, which leads to more organizational commitment and decreases the probability of quitting. Some of their findings indicate that satisfaction and commitment are distinguishable though moderately-related variables, and that they each contribute uniquely to turnover intention, which again is confirmed as the stronger predictor of turnover.

In a meta-analysis conducted as an update of a previous study (Hom \& Griffeth, 1995), Griffeth, Hom, and Gaertner (2000) found that the following proximal precursors in the turnover process were the best predictors: job satisfaction, organizational commitment, and intention to quit. More recent research done by Mitchell et al. (1999) suggests that the "employee embeddedness" levels highly correlate with the decision to quit. The less an employee is attached to the organization, the more likely the employee is to quit. This research supports "The Unfolding Model of Turnover" presented by Lee and Mitchell (1994) where several reasons, other than those related to dissatisfaction or job attitudes, were studied.

Maertz and Campion (2004) integrated the use of process models of turnover which analyze "how people quit," and content models which focus on "why people quit." These last three articles (Mitchell, 1999, Lee \& Mitchell, 1994, and Maertz, 2004) proposed that individuals with different propensities will act in different ways. Many of the same factors discussed by previous researchers continue to affect the decision to quit.

\section{Management Theories}

The Management Theory Jungle, written by H. Koontz in 1961, claimed that a "flood" of management theories created a great deal of confusion (Lemak, 2004). Koontz indicated concerns with the proliferation of management schools which tried to discredit earlier theories while defending their new ones. Koontz separated these schools of management theory into six groups: management process, empirical, human behavior, social system, decision theory, and mathematics schools. Later, Koontz (1980) added another five groups to the list. This created even more confusion, and he concluded that not much progress had been made (Lemak, 2004).

David J. Lemak (2004) proposes that management consists of three paradigms: classical, behavioral and systems. The classical theories were presented from the late 1800's through the 1920's. In the 1930's, the human relations theories gave way to the behavioral theories as they matured after the Great Depression. The systems theories were generated during the 1950's.

Classical paradigm. The classical paradigm focuses on the individual as the unit of analysis. It pays more to those who produce more. This is described by Fredrick Taylor as the "differential piece rate." The emphasis was on economic incentives, which were heavily criticized in early books. Most of the seminal writers of the time had an engineering background; therefore, applying science or mathematics to management was a natural approach. It was also easy for the well-trained workers to see the results of their discipline translated into their paychecks. The main duties of managers were to design the job, train the workers, and ensure the work was done correctly. Managers were 
mostly concerned with how the workers did their job. A manager using the classical theory is both a planner and a trainer.

Behavioral paradigm. The behavioral paradigm focuses on the group, not the individual. Based on the principle that people are driven first by emotion and not reason (Lemak, 2004), this theory explains that the organization becomes more than just a profit-making entity; it becomes a vehicle for social change, and a place where workers are interested in maintaining their relationships with co-workers on a personal level. A manager using the behavioral theory is a facilitator and team builder.

Systems paradigm. The systems paradigm is credited to Chester Barnard, who introduced it into the literature. Barnard defines it as "a system of consciously coordinated activities or forces of two or more persons" (Lemak, 2004). The key idea behind this paradigm was derived from the efforts during World War II to improve radar technology. Norbert Wiener coined the term "cybernetics," which refers to the concepts of self-regulation and constant feedback (Lemak, 2004). A manager using the systems paradigm focuses on interrelationships within the subsystems, and between the system and external influences.

The fast pace of our scientific and technological environment has helped propagate new theories which have easily spread throughout the world. Kuo-Wei Lin (2005) discusses in his article, "Managerial Thinking in the $21^{\text {st }}$ Century," the reform and development of management thinking over the last 20 years and how Peter Drucker has continued to positively influence the industry. Drucker (1974) expands on Fayol's original theories (1949) which are too limited and difficult to apply to large enterprises. Drucker proposed management by objective, outlining five basic principles of management: goal setting, organizational design, motivation and communication, measuring corporate performance, and education and training (Lin, 2005). Drucker's postulations were considered true management theory by Peters and Waterman in their book, In Search of Excellence (1982), when these authors discovered that more than $70 \%$ of 500 large companies selected by Fortune Magazine had applied Drucker's management theory.

Lin (2005) presents how traditional management has been challenged by the transformation of thought in the following five areas: value of knowledge as a factor of production, variation of leadership power, evolution toward an external environmental strategy, advent of the era of hyper-competition, and perfection of the decision-making model. Lin asserts that companies which do not sense change and adjust to it, and continue to apply the "old management models" when faced with "great changes in their business environment will gradually fall into trouble."

Douglas McGregor (1960) proposed two theories related to motivation. He labeled them Theory X and Theory Y. Both theories begin with the premise that management's role is to assemble the factors of production, including people, for the economic benefit of the firm. After that, these two theories diverge. Theory $\mathrm{X}$ assumes that the average worker dislikes work, attempts to avoid it, has no ambition, wants no responsibility, would rather follow than lead, is self-centered, does not care about the organization's goals, resists change, is gullible, and is not particularly intelligent. This theory does not apply to most workers because they require more than a job; they want to satisfy their higher-level needs. Theory $\mathrm{X}$ leaves no room for development or growth of the worker. Theory $\mathrm{Y}$ assumes that workers have higher-level needs through which they can be better motivated. This theory requires the following general assumptions: work can be as natural as play and rest; people will be self-directed to meet their work objectives if they are committed to them; people will be committed to their objectives if rewards are in place that address higher needs, such as self-fulfillment; and most people can handle responsibility because creativity and ingenuity are common in the population. Under these assumptions, there is an opportunity to align personal goals with that of the organization by utilizing the workers' quest for fulfillment as their motivator.

Sumantra Ghoshal (2005) wrote a very interesting article published by the Academy of Management Learning \& Education, entitled "Bad Management Theories are Destroying Good Management Practices." Ghoshal calls for a drastic change in how business schools teach management theories. He specifically targets courses on corporate governance (which are derived from the agency theory), where the students are taught that managers cannot be trusted to do their jobs. The current view of the manager's job is mainly to maximize shareholder value and to overcome agency problems. Companies offer incentives intended to maximize shareholder value. 
Ghoshal also asserts that business schools and researchers have "adopted the scientific approach of trying to discover patterns and laws, and have replaced all notions of human intentionality with a firm belief in causal determinism for explaining all aspects of corporate performance." Many have ignored the fundamental differences among academic disciplines, and have adopted similar methods to those researching the physical sciences under the "pretension of knowledge." As a result, these present management theories employ very causal or functional explanations. The exclusion of human characteristics, such as ethics and morality, from the theories has also eliminated them from the practices followed by business leaders.

According to Ghoshal, the stakeholder theory is only applied to shareholders. He explains that there are other "principals" involved, but including these would complicate the mathematical principal-agent model due to the difficulty of assigning a numerical value to human factors such as social effect and morality. In current practices influenced by this theory, contributions by shareholders of financial capital are more important than the contributions of human capital provided by managers and workers. The predictive power of these agency theories is very limited and has little effect on corporate performance, according to Ghoshal.

Michael Rubach (2005) conducted a study of 141 firms to review the effect on stock prices after the adoption of corporate governance guidelines. He found that "with respect to stock prices' reactions to the announcements, there are no significant daily or cumulative reactions for any year." He further explains that the failure to receive any benefit has induced many firms to stop announcing the adoption of these guidelines.

In the article "A Critique of Stake-Holder Theory: Management Science or a Sophisticated Ideology of Control?" written by Antonacopoulou and Meric (2005), there is a comment from Popper (1963) which summarizes the article. Popper says that "a theoretical corpus that can provide exhaustive explanations of observed phenomena and that, at the same time, can integrate previously formulated knowledge belongs to the field of ideology." Criticizing this absorption process helps to clarify the ideological aspects of stake-holder theory (Antonacopoulou, 2005).

Thomas Kochan (2002) explains why the recent corporate scandals in the United States have occurred. He says that "it lies in this over-emphasis American corporations have been forced to give in recent years to maximizing shareholder value without regard for the effects of their actions on other stake-holders" (Ghoshal, 2005). Ghoshal (2005) yet again criticizes business schools when he presents the different kinds of scholarships [discovery (research), integration (synthesis), practice (application), and teaching (pedagogy)], and affirms that we have lost the taste for pluralism. He writes, "what started off as an entirely justified effort for introducing the scholarship of discovery to the study of business has ended up in the excess of eliminating all other forms of scholarship from the world of business schools." He asks, "what would happen if we reversed the trend so as to provide some space for these people and judge them not on their scientific credentials but on their practical knowledge?"

There are several other professors who wrote articles in the same issue of the Academy of Management Learning \& Education (March 2005) who weigh in with their opinions about Ghoshal's pronouncements regarding theories of management and business schools. Lex Donaldson (2005) disagrees that the scientific approach causes problems and that it should be disregarded. However, Donaldson is in agreement with Ghoshal on most of the other topics. Henry Mintzberg (2005), a personal friend of Ghoshal, does not go into much detail about his opinion regarding the pronouncements made by his friend, but says that he has a quarrel with the amount of influence that Ghoshal gives these theories on social discourse. Mintzberg wishes those theories were that influential. He also has another "tiny" quarrel with Ghoshal's assertion that the kinds of thinkers and researchers needed in business schools are now outside the mainstream. He says that was not true when we had people like Ghoshal in the mainstream.

Like Donaldson, Donald C. Hambrick (2005) disagrees with the assertion that the adoption of the scientific approach is at odds with the role of human behavior. John Gapper (2005) finds some exceptions with the topic of business schools not caring about ethics and moral issues. Gapper writes that these individuals who acted outside the code of ethics and morality most likely did not learn that at the business schools, but at home when they were growing up. Jeffrey Pfeffer (2005) agrees with Ghoshal on most of his ideas, and goes further by writing that "it is even worse than Ghoshal maintains." He adds that another phenomenon is the fact that these theories become self-fulfilling; once accepted as true, processes begin to unfold which make the theories true. Pfeffer and Fong (2004) have also argued 
that many business schools pursuing money and status have "lost their way and their professional mission" (Pfeffer, 2005).

\section{ANALYSIS AND REFLECTIONS}

For many decades, researchers, scholars, and managers have searched for the most efficient and effective ways to manage people. Many theories have been put in practice. A few theories have established the proper way to manage people and motivate them to do a good job while being committed to the job and the organization.

Management theories started with the classical/scientific approach, which developed at the turn of the twentieth century and continued well into the 1930's. These theories evolved from the legacy of the Industrial Revolution and the social structure of the times. There was a large workforce of relatively uneducated, disempowered people. These classical/scientific theories supported management principles based on hierarchical systems such as specialization, centralization, and formality. The span of control was very narrow, and a single line of command was in place. Consumers may have seen some benefits, such as the availability of a wide range of consumer goods. However, the problems caused by the dehumanizing and autocratic nature of the efficiency-driven systems produced many conflicts because the needs of the workers were not equated with those of management.

While these theories improved productivity and had a significant impact on industry, they contributed to the monotony of the work. Other drawbacks were the lack of skill variety, task significance, autonomy, and feedback. Despite all of the above-mentioned drawbacks, these theories changed the way people worked then, and some of these principles are still in use today.

The behavioral/human theories followed between 1922 and 1970. These changed how managers approached human aspects and the emerging significance of work groups. The results of the Hawthorne studies influenced managers to focus more on supportive group leadership and to promote a wide span of control within a flat organizational structure. A major belief was that the organization would prosper if the employees also prospered. The needs of the workers were the responsibility of the newly-created human resource departments.

The fast-growing, competitive world economy and the crisis in the western enterprises gave rise to the systems/contingency theories which were reactive to the organizational environment. These started in the 1960's and lasted into the late 1970's. Management adopted techniques that integrated norms, values, and beliefs instead of the commands from superiors. Managers realized there was more than one way to handle various circumstances. These principles resulted in improved practices in organizational design and leadership. One important effect of this theory was that managers looked at the organization from a broader prospective by interpreting patterns and events within their departments. They also considered how their departments interrelated with others in the company and with outside elements.

Loosely-structured networks and alliances helped to develop the political/collaborative theories prevalent from the 1980's to the present. The high levels of social, economic, and technological discontinuity influenced managers to use political approaches to react to the fast rate of change and complex external environment. Managers began to experiment with new strategies to derive solutions to unstructured problems. The move has been toward decentralization and more deliberate strategies to deal with complex environments.

Value-driven management. Another practical theory is value-driven management. This theory postulates an integrative philosophical framework within which to make decisions and take action (Pohlman \& Gardiner, 2000). It takes into consideration how the actions of all relevant groups affect the value of the organization. This theory also incorporates other theories that help to increase the organizational value. Pohlman and Gardiner (2000) say: "valuedriven management is not a simple formula for success, a rigid system to be arbitrarily followed, or an ideology." Value-driven management theory advocates value congruency among employees, owners, suppliers, customers, and the organization, while it also attempts to integrate the competitors and third party values. Pohlman and Gardiner claim this model can help modify how people view their jobs, which improves the success of the organization. 
Market-based management. In 1991, Charles G. Koch, chairman and CEO of Koch Industries, began to call the management philosophy that he developed and used for more than 25 years "market-based management." Marketbased management is designed to analyze the structures, responsibilities, values, and incentives that motivate the entire staff (managers and employees) to work toward a common mission (Gable \& Elliq, 1993). Operating as a democratic and participative system, the design resembles free society and gives a voice to every member of the staff. This participative voice applies to minor and major decisions directly or indirectly through elected representatives. This theory involves dividing the decision-making process so that the individual or group with the true knowledge of the issues and the right incentives tied to the outcome makes the decision and bears the responsibility for the outcome (Gable \& Elliq, 1993). Koch Industries divides its mission system into four key elements: understanding the business, deciding what to do, planning how to do it, and monitoring progress (Gable \& Elliq, 1993). To start the process, Koch utilized three complementary objectives: to make sure that the entire conceptual framework and principles were properly articulated, that the entire staff understood it, and aligning all the company's activities. This alignment assured consistency with the principles of market-based management (Gable \& Elliq, 1993).

Management in practice. In order to analyze how ineffective management theories impact the decision to quit, the relationship between management theory and management practice must be reviewed. There is ample support in the literature that job satisfaction and organizational commitment are very important variables affecting the intention to leave as well as the actual quitting. Employees' levels of satisfaction and organizational commitment are affected by many variables; the manner in which they are treated by managers implementing management's directives is one of the most significant elements.

The literature also supports the concept that different propensities to react are found to affect the decision to quit. In reviewing the Unfolding Model of Turnover, it is evident that many of the decisions to quit result from what the model calls a "shock," which is described as "a particular, jarring event that initiates the psychological analyses involved in quitting" (Lee et al., 1994). One of the cited possible shocks is a serious conflict with coworkers and/or supervisors.

Most management theories aim to address possible events so these situations can be anticipated and controlled. The validity of these theories partly depends on their successful use in management practices. Management knowledge occurs after basic and pure research is conducted by academics and scholars. These concepts are then communicated to managers and others, typically via articles or books. Human resource specialists or consultants design the procedures through which these theories are applied, and finally, managers put them into practice. Some portions of management theories are never put into practice by managers because they lack realworld, practical application. Abrahamson and Fairchild (1999) explained that in the early 1990's, the theories of quality circles and quality management were embraced by both scholars and managers, but only the basic terminology (and not the concepts) was adopted.

Employee turnover. Understanding employee turnover as well as its sources in the company, and adopting specific strategies to positively impact it is a good start in preventing experienced and productive employees from leaving the organization. Since employee turnover can be disastrous, employers naturally worry about the direct and indirect costs of turnover as it can have economic consequences. Consequently, organizations (employer) as contributors to the well-being of their employees, must decide on how to produce, for whom to produce, how to provide for the growth of the system, and decide how to ration resources in the system (Udechukwu \& Mujtaba, 2007a). According to Udechukwu and Mujtaba (2007a, 2007b), the term "produce" is a general and common economic term depicting the act of productivity. Management's duty, as with the employer, is to make the organization perform well by orchestrating the use of manpower, money, machine, and materials to accomplish organizational goals. Thus, the well-being of employees inside and outside of the organization is important.

While most voluntary turnover models are designed to illustrate direct and/or indirect linkages of work related antecedents and determinants to work outcomes such as turnover, intentions of quitting, absenteeism, etc., Udechukwu and Mujtaba's 2007article presented a theoretical model (see Figure 1) as an enabler in the development of the mathematical model. 
Udechukwu and Mujtaba's theoretical model in Figure 1 visually illustrates the intended multidisciplinary (social, economic, and psychological context) and multidimensional (employee, employer/organization, and social affiliates) state of voluntary turnover in organizations. While the model is designed to simply show the interaction between the variables presented in their study, the authors do acknowledge that economic forces can operate directly on an employee and not just through social affiliates. In addition, the elements of the model are linked not to show cause and effect, but to show that all employees face directly and indirectly the forces associated with their social affiliates and directly and indirectly, the forces associated with their employer.

Figure 1- Employee-Organization Turnover Impact Diagram (Udechukwu \& Mujtaba, 2007)

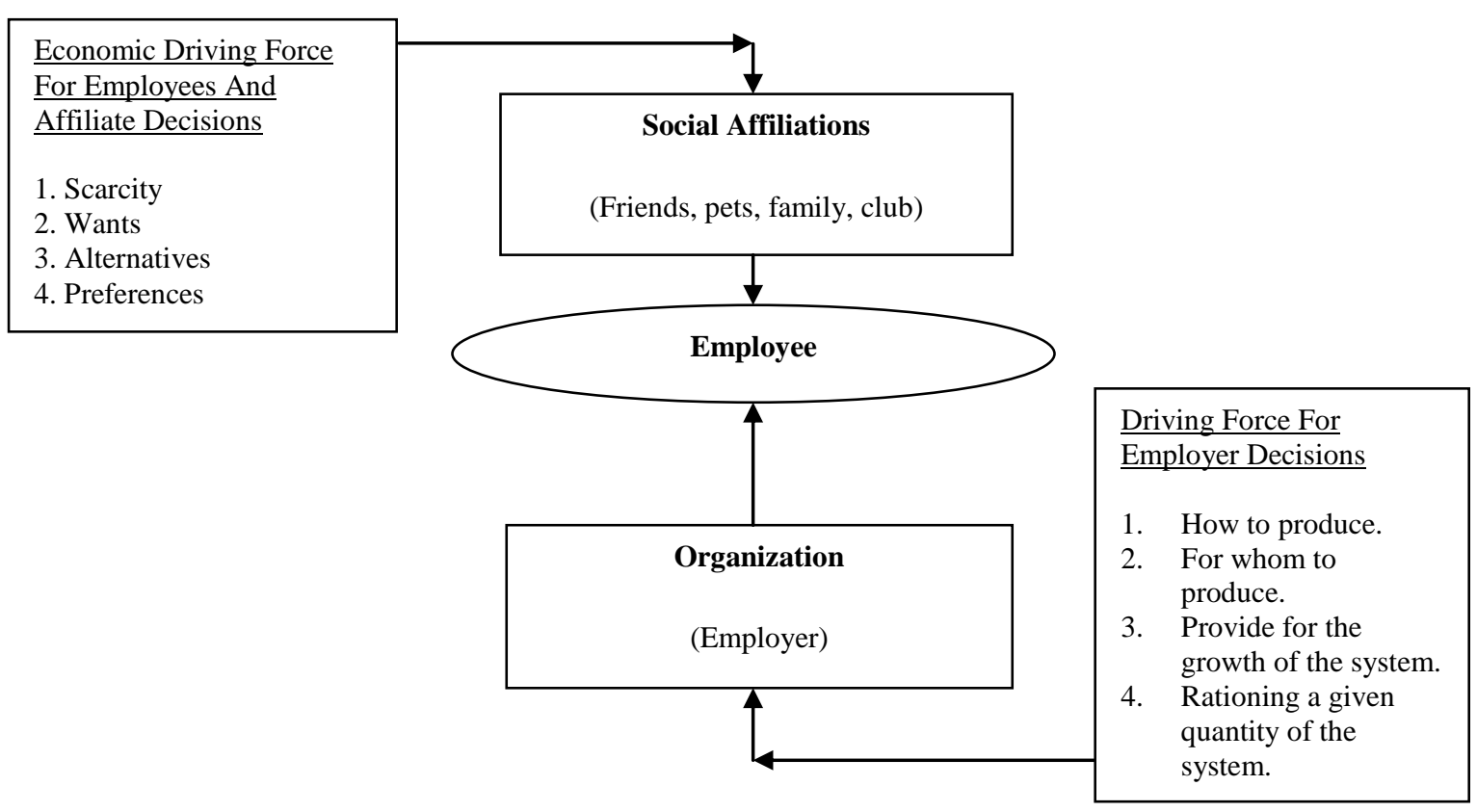

In essence, the model suggests that employees reference their affiliation to the social affiliate (entity or activity) when conducting comparisons and/or making comparative decisions while in the organization based on the intended "advantages" received from the employer/organization, before intentions to turnover or quitting fully surfaces in the employee's psyche. Thus, the employee is in essence seeking an economic, social, and psychological equilibrium between his/her desired needs/expectations that can be provided as a consequence of their association with the employer and mentors within the organization (Mujtaba, 2007). When the employee's basic needs go unsatisfied, his or her psychological and physical health as well as their productivity tends to suffer. Employees must maintain a healthy balance or equilibrium between the need or standards of their social affiliates (entity or activity), their own personal needs, and the "advantages" received from the organization. Thus, the authors argues that voluntary turnover occurs when there is a discrepancy between "advantages" received by the employee from the organization and the "advantages" supplied by the employer.

Management in the service industry. After working as managers for over fifty years in the banking and service industries, the authors have witnessed how the job of a teller or front sales people has deteriorated from a very important position (providing high levels of affiliation and economic incentives) to one now occupied by inexperienced employees who have the highest level of voluntary turnover (leading to low levels of affiliation and economic incentives). For example, retailers usually hire for cashier and clerk positions people without much experience or history in the industry. Furthermore, these employees are often the lowest paid workers and they tend to receive very little training about the firm or quality service. The same scenarios can be found in the banking industry as well. However, top bank managers in most banks have always expressed the belief that the job of a teller is the "most important job." As demonstrated from the generic organizational chart in Figure 2, the reality is that banks 
place individuals with zero or very limited experience in these positions, assign tellers the lowest salary range, and, thus implicitly, treat them as if they were unimportant. Certain management theories, such as the agency theory and the corporate governance theory, which mostly seek to maximize stockholders' value, are responsible for the deteriorating working conditions of bank tellers.

The job of a teller today requires a particular skill set that makes the position not only a difficult one, but also critical and essential to the success of any bank. Tellers must possess the following five important characteristics: 1) highly acute people skills; 2) excellence at counting currency and recognizing counterfeit bills; 3) computer literacy; 4) knowledge of legal issues, such as proper endorsements, authorized signatures, and negotiability of monetary instruments; and 5) a sales-oriented mindset in order to cross-sell services that customers are not using. If these frontline employees are being expected to possess such a variety of cognitive and perceptual skills, then it only makes business sense that they also need to be paid well and receive excellent ongoing training. The success and positive consequences of truly valuing the frontline employees can be seen from the practices of such firms as Starbucks, Nordstrom and many others have done a good job of truly valuing the frontline employees as they either make or break the company's "brand" perception.

Figure 2- Generic Organizational Chart for Banks

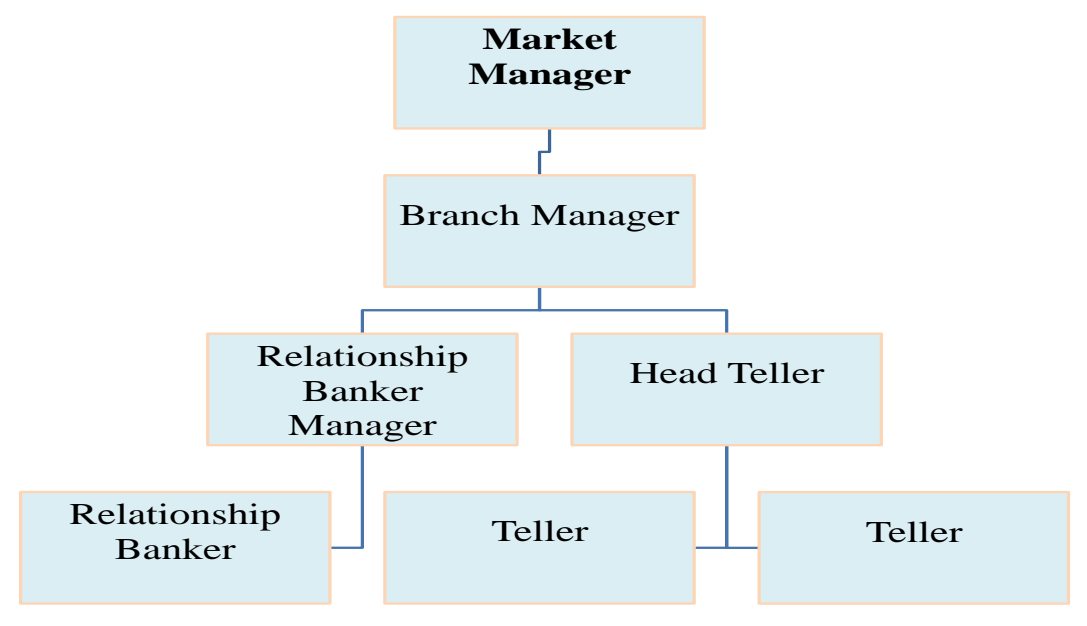

Approximately 40 years ago, banks used to promote good employees from other departments to the teller position. In many countries where the banking industry was unionized, the position of a teller was the highest nonofficer position on the union scale. Tellers were promoted to assistant managers, and later to managers, because they had the experience of working in most of the other departments of the bank. Even about 20 years ago, the position of a teller was deemed very important to those making the decisions about pay and status. However, significant trends have occurred since then that have impacted these decisions: automation and industry consolidation.

Automation, even though very beneficial, has minimized the need for many of the skills that tellers required before. It has also created the need for a set of new skills; however, most of them are "robotic" in nature and do not require high intellectual ability and years of experience. Tellers used to rely more on their knowledge of the customer and his or her record than on what the computer terminal tells them. Their job used to require experience and good memory. Many customers today do not even come into a branch to see a teller for their transactions because they do all of them online and via automation. This trend will continue, and will probably result in most banks needing fewer tellers. Those left will need to have the experience and customer skills required to handle the more complex transactions, and to serve those customers who continue to visit the branch for their transactions.

Industry consolidation has brought both positive and negative outcomes to customers and banks. Reduction in the number of tellers is one of the more significant outcomes. When two banks merge or one acquires another, they 
invariably have branches that are redundant. When these branches are consolidated, the number of tellers is reduced, although the number of customers does not immediately decrease. Industry consolidation has also been influenced by the theories that seek to increase stockholders' value above all else.

This situation causes longer lines and more stress on customers and tellers, and also risks the loss of both customers and tellers. In addition, the salary component of this situation creates some interesting ramifications. For example, when two branches of different banks in the same interception merge, the number of tellers is reduced to save money, but the activity level does not decrease. Therefore, tellers have to work harder for the same pay and under less desirable conditions. Tellers frequently become dissatisfied and quit.

Organizational commitment is another variable that has deteriorated over time in the banking industry, mainly for the same reasons. In addition to causes such as automation and consolidation, organizational commitment has also decreased because tellers and other employees in general, do not feel the organization is committed to them so they do not commit themselves to the organization. According to much of the literature reviewed above, one of the main reasons why turnover is very high and organizational commitment is low among bank tellers is generally because they do not feel recognized as an important part of the team.

According to the U.S. Department of Labor's Bureau of Labor Statistics in August 2004, the overall nationwide voluntary turnover rate was $20.2 \%$. The highest rate was experienced by those in accommodation and food services (44.4\%), while the lowest was in educational services $(9.8 \%)$. The rate for financial institutions, including banks, was $14.1 \%$. These numbers are unacceptable after so many years of research, development, and implementation of management theories. Proper leadership from the line supervisors is needed, as well as management practices that allow supervisors to be effective leaders.

What can managers and supervisors do? Supervisors wield powerful influence over their employees' attitudes toward the company. Perhaps organizations can flip their organizational charts upside down so as to communicate the importance of frontline employee positions. Since they are the first point of contact, these are the employees that communicate the brand of the organization to everyone they speak or interact with periodically or on a regular basis. Besides changing the organizational chart, employers should also provide relevant economic incentives to retain their employees and to keep them highly satisfied and productive. The lack of proper communication and dialogue causes some of the competent employees to quit. Employees need effective and honest communication from their direct supervisor if they are to achieve high productivity and remain on the job. Progressive employers are starting to hold managers responsible for retaining talented employees. In doing so, managers are focusing on relationships and careful assessment of subordinates' work-related behaviors. Regular discussions of employees' ideas about the organization and its management practices will give the supervisors clues as to the propensity of these direct reports to quit. Trust between the supervisor and the employee is vital in shaping how the employee views the company. If the supervisor exhibits integrity, the subordinates will recognize that the same is expected of them. Consistent decision-making and proper follow-up will help to increase the value of the employee's relationship with the supervisor and the company.

Employees must also have meaningful work and the autonomy to do it well. When this occurs, the employees feel the supervisor and the company have confidence in them. Conversely, if the supervisor micromanages the employees, it implies that he or she has very little confidence in the employees and sees no potential for growth and development.

Choosing the right employee is also an important way to minimize voluntary turnover. There is evidence that personal characteristics help shape subsequent work attitudes and behaviors (Lee \& Mowday, 1992). Classification of the job is also critical. If a job as important as a bank teller is classified as entry-level, the person hired will not feel that it is an important position or that others perceive that their job is important.

Many senior managers support the thesis that banks can reduce voluntary turnover of tellers. However, they must first elevate the teller's job importance level to where it once was by requiring tellers to have at least three years of experience in other bank support departments. Second, management must increase the tellers' salary to a competitive level. Third, banks must increase the authority of tellers so they can make certain important customer- 
service decisions without looking for a supervisor's approval. The increase in salary will help reduce the level of dissatisfaction, and will send a message to the tellers and others in the company that the job is important. Increasing the level of authority will enrich their jobs and prepare them for supervisory positions in the future. This will also increase their level of satisfaction, which will have a positive effect on their organizational commitment, and hence reduce voluntary turnover.

\section{SUMMARY}

Do certain management theories have a negative effect on practices such that voluntary turnover increases? The answer is a resounding "yes." Ghoshal (2005) says that nothing is as dangerous as bad theories because they destroy good management practices. When workers have to operate under a manager who applies ineffective management theories in their departments or applies them inappropriately, then the employees' motivation tends to decrease, they may seek alternative jobs, and they are more likely to eventually quit and possibly join the firm's competitors.

The literature reviewed in this paper and the authors' fifty years of combined experience support the assumptions that many front service personnel and bank tellers are often dissatisfied with their pay and are not motivated to develop a strong organizational commitment. The analysis of many management theories reveals that most of the recent concepts focus on increasing stockholder value, and do not always consider the total value provided by the employees, their work, and their knowledge. Companies like Starbucks, Nordstrom and many others have done a good job of truly valuing the frontline employees as they either make or break the company's "brand" perception. Similarly, in the financial industry, bank tellers are the "face of the bank." Therefore, they deserve to be paid fairly well and given the status and responsibilities that will improve their jobs. As a result, the bank's customers will be better served, and voluntary turnover will be reduced.

\section{AUTHOR INFORMATION}

Rolando M. Ochoa was born in Cuba. He became a political refugee into the U.S. in October 1962. Since then, he has served in the U.S. Army during the Viet Nam conflict, as a bank executive since 1970, and as an adjunct professor of business administration in South Florida for 17 years. He earned an MBA from the University of Miami and is completing a doctoral degree in management at Nova Southeastern University. Rolando has been married since 1965 with six children and four grandchildren.

Bahaudin G. Mujtaba is currently an Associate Professor of Management, Human Resources and International Management. He is also the Department Chair for Management at Nova Southeastern University's H. Wayne Huizenga School of Business and Entrepreneurship in Fort Lauderdale, Florida. Bahaudin has worked as an internal consultant, trainer, and teacher at Training and Development Department of Human Resources as well as retail management in the corporate arena for 16 years. Academically, Bahaudin is the author and co-authors of about fifteen books in the areas of management, ethics, and cross-cultural management. Bahaudin can be reached through email at: mujtaba@nova.edu.

\section{REFERENCES}

1. Abrahamson, E. \& Fairchild, G. (1999). Management Fashion: Lifecycles, Triggers, and Collective Learning Processes. Administrative Science Quarterly, 44, 708-740.

2. Antonacopoulou, E. P. \& Meric, J. (2005). A Critique of Stake-Holder Theory: Management Science or a Sophisticated Ideology of Control? Corporate Governance, Bradford, 5-2, 22-34.

3. Donaldson, L. (2005). For Positive Management Theories While Retaining Science: Reply to Ghoshal. Academy of Management Learning \& Education, 4-1, 109-113.

4. $\quad$ Ducker, P. F. (1974). Management: Tasks, Responsibilities, Practices. London: Hieneman: New York: Harper and Row.

5. Fayol, H. (1949). Industrial and General Administration, (trans.) by Storrs, C. London: Pitman.

6. Fishbein, M. (1967). Attitude and the Prediction of Behavior. In M. Fishbein (Ed), Readings in Attitude Theory and Measurements. New York: Wiley. 
7. Gapper, J. (2005). Comment on Sumantra Ghoshal's “Bad Management Theories are Destroying Good Management Practices." Academy of Management Learning \& Education, 4-1, 101-103.

8. Ghoshal, S. (2005). Bad Management Theories are Destroying Good Management Practices. Academy of Management Learning \& Education, 4-1, 75-91.

9. Griffeth, R. W., Hom, P. W., \& Gaertner, S. (2000). A Meta-Analysis of Antecedents and Correlates of Employee Turnover: Update, Moderator Tests, and Research Implications for the Next Millennium. Journal of Management, 26-1, 463-488.

10. Hambrick, D. C. (2005). Just How Bad are Our Theories? A Response to Ghoshal. Academy of Management Learning \& Education, 4-1, 104-107.

11. Herzberg, F., Mausner, B., Peterson, R. O., \& Capwell, D. F. (1957). Job Attitudes: Review of Research and Opinion. Psychological Service of Pittsburg.

12. Herzberg, F., Mausner, B., \& Snyderman, B. B. (1959). The Motivation to Work (2 ${ }^{\text {nd }}$ Ed.). New York: John Wiley and Sons, Inc.

13. Kraut, A. I. (1975). Predicting Turnover of Employees from Measured Job Attitudes. Organizational Behavior and Human Performance, 13, 233-243.

14. Lee, T. W., Ashford, S. J., Walsh, J. P., \& Mowday, R. T. (1992). Commitment Propensity, Organizational Commitment, and Voluntary Turnover: A Longitudinal Study of Organizational Entry Process. Journal of Management, 15, 120-133.

15. Lee, T. W., \& Mitchell, T. R. (1991). An Alternative Approach: The Unfolding Model of Voluntary Employee Turnover. Academy of Management Review, 19, 51-89.

16. Lemak, D. J. (2004). Leading Students Through the Management Theory Jungle by Following the Path of the Seminal Theorists: A Paradigmatic Approach. Management Decision, London. 42-10, 13091326.

17. Lin, K. W. (2005). Managerial Thinking in the $21^{\text {st }}$ Century. Journal of American Academy of Business, Cambridge. 6-1, 195-200.

18. Locke, E. A. (1976). The Nature and Causes of Job Satisfaction. In M. D. Dunnette (Ed). Handbook of Industrial and Organizational Psychology. Chicago: Rand-McNally.

19. Locke, E. A., Cartledge, N., \& Knerr, C. S. (1970). Studies of the Relationship Between Satisfaction, Goal-Setting, and Performance. Organizational Behavior and Human Performance, 5, 135-158.

20. Maertz, C. P., \& Campion, M. A. (2004). Profiles in Quitting: Integrated Process and Content Turnover Theory. Academy of Management Journal, 47, 568-582.

21. March, J. G., \& Simon, H. A. (1958). Organizations. New York: Wiley.

22. Mintzberg, H. (2005). How Inspiring. How Sad. Comment on Sumantra Ghoshal's Paper. Academy of Management Learning \& Education, 4-1,108.

23. Mitchell, T., Holtom, B., Lee, T., Sablynski, C., \& Erez, M. (1999). The Retention of Employees: The Role of Organizational Embeddedness. Academy of Management Conference.

24. Mobley, W. H. (1977). Intermediate Linkages in the Relationship Between Job Satisfaction and Employee Turnover. Journal of Applied Psychology, 62, 237-240.

25. Mobley, W. H., Griffeth, R. W., Hand, H. H., \& Meglino, B. M. (1979). Review and Conceptual Analysis of the Employee Turnover Process. Psychological Bulletin, 86-3, 493-522.

26. Mobley, W. H., Horner, S. O., \& Hollingworth, A. T. (1978). An Evaluation of Precursors of Hospital Employee Turnover. Journal of Applied Psychology, 63-4, 408-414.

27. Mujtaba, B. G. (2007). Mentoring Diverse Professionals, $2^{\text {nd }}$ Edition. Llumina Press, FL. ISBN: 1-5952644-34.

28. Pfeffer, J. (2005). Why Do Bad Management Theories Persist? A Comment on Ghoshal. Academy of Management Learning \& Education, 4-1, 96-100.

29. Pohlman, R. \& Gardiner, G. (2000). Value Driven Management: How to Create and Maximize Value Over Time for Organizational Success. Amocom Books.

30. Porter, L., Steers, R. M., \& Mowday, R. T. (1974). Organizational Commitment, Job Satisfaction, and Turnover Among Psychiatric Technicians. Journal of Applied Psychology, 59, 603-609.

31. Rubach, M. (2005). The Enactment of Corporate Governance Guidelines: An Empirical Examination. Corporate Governance, Bradford. 5-5, 30-39.

32. Steers, R. M., \& Porter, L. (1983). Employee Commitment to Organizations. In R. Steers \& L. Porter (Eds.) Motivation and Work Behavior, 218-230. New York: McGraw Hill. 
33. Tett, R. P., \& Meyer, J. P. (1993). Job Satisfaction, Organizational Commitment, Turnover Intention, and Turnover: Path Analyses Based on Meta-Analytical Findings. Personnel Psychology, Vol. 46: 259-294.

34. Udechukwu, I. I. and Mujtaba, B. G. (June 2007a). Determining the probability that an employee will stay or leave the organization: a mathematical and theoretical model for organizations. Human Resource Development Review, Vol. 6, No. 2; pages 164-184.

35. Udechukwu, I. I., \& Mujtaba, B. G. (2007b). Employee turnover and social affiliation. In B. G. Mujtaba (Ed.), Mentoring Diverse Professionals, second edition. Pages 179-190. ISBN: 1-595-2644-34. Llumina Press, Florida.

36. Udechukwu, I. I. \& Mujtaba, B. G. (2006). Job satisfaction and organizational commitment. In B. G. Mujtaba \& F. J. Cavico (Ed.), Age Discrimination in Employment: Cross Cultural Comparison and Management Strategies. Pages 174 188. ISBN: 1-4196-1587-4. BookSurge Publishing, Florida.

37. Udechukwu, I. (2003). The mechanics of microeconomic choice: A school option perspective. Essays in Education, 8, 1-18.

38. Williams, L. J. \& Hazer, J. T. (1986). Antecedents and Consequences of Satisfaction and Commitment in Turnover Models: A Re-Analysis Using Latent Variable Structural Equation Methods. Journal of Applied Psychology, Vol. 71-2, 219-231.

39. Youngblood, S. A., Mobley, W. H., \& Meglino, B. M. A. (1983). Longitudinal Analysis of the Turnover Process. Journal of Applied Psychology, 68-3, 507-516. 
Journal of Business \& Economics Research-August, 2009

Volume 7, Number 8

\section{NOTES}

